\title{
Psychiatric Rehabilitation Programs for Peoples with Disabilities: Literature Review
}

\author{
Leyla Küçük* and Tuba Çömez \\ Department of Mental Health and Psychiatric Nursing, Istanbul University, Turkey
}

Submission: June 14, 2017; Published: July 5, 2017

*Corresponding author: Leyla Küçük, Department of Mental Health and Psychiatric Nursing, Istanbul University, Turkey, Tel: 0090-212-440-0000/27074; Email: leylak73@istanbul.edu.tr

\begin{abstract}
Hereditary factors and stigma in disabled people increase the possibilities of unemployment, environmental factors including adverse life experiences and psychiatric problems.Studies have shown that psychiatric problems in disabled people are five times higher than other people in the community. For this reason, besides treatment programs rehabilitation programs that enable psychiatric strengthening are needed to reintegrate disabled people into society and to enable them live their lives on their own or with minimum support. Psychiatric rehabilitation programs were revised through this mini-literature review and it is seen that the programs improved problem solving skills in disabled people, increased perceptions of family communication and social support, increased self esteem and decreased anxiety and depression symptoms.
\end{abstract}

Keywords: Disability; Disabled person; Psychiatric rehabilitation; Psychoeducation; Evidencebased practices

\section{Introduction}

Disability is a phenomenon which is characterized by difficulties in adapting to social life and meeting the needs of daily life because of the loss, by birth or later for any reason, of physical, mental, spiritual, sensory and social skills at various grades and it needs support services such as prevention, care, rehabilitation and counseling [1]. Prenatal, at birth and postnatal causes play a role in the occurrence of disability. It is classified in seven groups as mental, physical, sight, hearing, language and speech, disability due to persistent diseases, and spiritual emotional disability [2]. According to World Health Organization (WHO) 2011 disability data, the rate of disability is accepted as $10 \%$ for developed countries and $15.6 \%$ for developing countries and it is estimated that 750 million to 1 billion people are disabled worldwide [3]. Disability rates have reached significant numbers all over the world and have recently been a serious issue to raise awareness on. In disabled people; the risk of biological disposition, unsuccessful experiences in social life, stigma perception and the occurrence of the psychiatric problems that are based upon stress effects originating from the individuals in family or in the environment are five times higher than the other individuals in the society [4]. Therefore, besides treatment programs rehabilitation programs that enable psychiatric strengthening are needed to reintegrate disabled people into society and to enable them live their lives on their own or with minimum support. Psychiatric rehabilitation is a comprehensive, coordinated and long-term treatment that is practiced to meet the mental and social needs of individuals with persistent symptoms and functional impairment [5]. In disabled individuals who are treated as private/different groups; this process progresses according to different and group specific needs because they have different problems than usual patients $[4,5]$. With this mini-literature compilation, it is aimed to review the "psychiatric rehabilitation programs" for disabled people which are a special group.

\section{Methods}

\section{Search methodology}

The study was carried out by retrospective scanning in the databases of the relevant publications. Studies, between JanuaryMarch 2017, were scanned via Istanbul University internet access network, with the keywords "psychiatric rehabilitation", "physical handicap", "physical disability", "mental/intellectual handicap-disability-retarded", "deaf", "deafness", "hearing impaired", "visually handicap-disability", "speech and language disability"; in the databases of Ulakbim, Turkish Psychiatry Index, Google Academic, Pubmed, CINAHL, and Cochrane. The 
thesis studies done on the subject and the leaflets presented in the congresses were not included in the scope of the study.

\section{Selection of studies}

The following criteria were taken into consideration in the selection of the articles to be included in the study;

a. The practiced psycho-rehabilitation program is towards disabled people,

b. Being a research article that can be reachable as a full text,

c. Language of the publication is either Turkish or English,

d. Being original and quantitative,

e. Published in a national/international refereed journal between 2000 and 2017 .

In the summarization of the data; a valid and reliable guideline for systematic reviews "A checklist of items that should be taken into account in the reporting of systematic compilation or meta-analysis studies" (Preferred reporting items for systematic reviews and meta-analyses statement -PRISMA-) was taken into account.

\section{Results}

Table 1: Tables of studies.

\begin{tabular}{|c|c|c|}
\hline Databases & $\begin{array}{c}\text { Number of Studies } \\
\text { Reached }\end{array}$ & $\begin{array}{c}\text { Number of Studies } \\
\text { Included }\end{array}$ \\
\hline ULAKBIM & 248 & 2 \\
\hline $\begin{array}{c}\text { Turkish Psychiatry } \\
\text { Index }\end{array}$ & 323 & -- \\
\hline Google Scholar & 2589 & 4 \\
\hline CINAHL & 322 & 1 \\
\hline Pubmed & 206 & 5 \\
\hline Cochrane & 3725 & 14 \\
\hline Total & 7413 & 2 \\
\hline
\end{tabular}

Table 2: Virtual Reality Therapy.

\begin{tabular}{|c|c|c|c|c|}
\hline $\begin{array}{c}\text { Title \& } \\
\text { Authors \& } \\
\text { Date }\end{array}$ & Aim of the study & Methods & Results & Conclusion \\
\hline [6] & $\begin{array}{l}\text { To investigate the effect of } \\
\text { virtual reality therapy on } \\
\text { psychological adaptation } \\
\text { in children with cerebral } \\
\text { palsy }\end{array}$ & $\begin{array}{c}\text { Randomized controlled study } \\
\text { Throughout } 4 \text { weeks; } 1 \text { hour per day } \\
\text { for } 3 \text { days a week, it was used with } \\
\text { Hacettepe Psychological Adaptation } \\
\text { Scale after virtual reality therapy } \\
\text { with Sony Play Station } 2 \text { and Eye Toy } \\
\text { system. } \\
\text { (N: } 41)\end{array}$ & $\begin{array}{l}\text { The practiced care program } \\
\text { was effective and it was found } \\
\text { that the post-treatment values } \\
\text { of the individuals in the experi- } \\
\text { mental group are better. }\end{array}$ & $\begin{array}{l}\text { Virtual reality therapy is a } \\
\text { useful treatment method } \\
\text { that can be used for SP } \\
\text { rehabilitation and improve } \\
\text { spiritual adaptation. }\end{array}$ \\
\hline [7] & $\begin{array}{l}\text { To examine the effect of } \\
\text { PECS program on social } \\
\text { communication in children } \\
\text { with autism }\end{array}$ & $\begin{array}{c}\text { A randomized controlled study } \\
\text { Throughout } 6 \text { months; for } 30 \text { minutes } \\
\text { a day/ once a week, PECS and speech } \\
\text { therapy was applied. It consists of } 4 \\
\text { stages. } \\
\text { (N:18) }\end{array}$ & $\begin{array}{l}\text { The practiced therapy program } \\
\text { was effective and scores of chil- } \\
\text { dren in the experimental group } \\
\text { were significantly higher when } \\
\text { evaluated after the } 4 \text { th stage. }\end{array}$ & $\begin{array}{l}\text { The practiced PECS } \\
\text { program has supported } \\
\text { the development of social } \\
\text { communication skills of } \\
\text { children with autism. }\end{array}$ \\
\hline [8] & $\begin{array}{l}\text { To examine the effect } \\
\text { of The Interpersonal } \\
\text { Communication Skills } \\
\text { Psycho-education Program } \\
\text { on empathic tendencies } \\
\text { and communication skills } \\
\text { of second grade primary } \\
\text { school students }\end{array}$ & $\begin{array}{l}\text { A randomized controlled study An } \\
\text { Interpersonal Communication Skills } \\
\text { Psycho-education Program consisting } \\
\text { of } 9 \text { sessions,Empathic Tendency Scale, } \\
\text { and Communication Skills Assessment } \\
\text { Scale were used. } \\
\text { (N = 16) }\end{array}$ & $\begin{array}{l}\text { When the values obtained from } \\
\text { measurements that made at } \\
\text { different times in the exper- } \\
\text { iment group were compared } \\
\text { with the values obtained from } \\
\text { those in the control group, they } \\
\text { were found to be different in } \\
\text { the positive direction. }\end{array}$ & $\begin{array}{l}\text { The ability of interpersonal } \\
\text { communication psycho-ed- } \\
\text { ucation program has been } \\
\text { effective in increasing the } \\
\text { empathic tendencies and } \\
\text { communication skills of } \\
\text { visually impaired adoles- } \\
\text { cents. }\end{array}$ \\
\hline [9] & $\begin{array}{l}\text { To learn experiences with } \\
\text { a structured program run } \\
\text { with visually impaired } \\
\text { adolescents }\end{array}$ & $\begin{array}{l}\text { A psychoeducation program consist- } \\
\text { ing of } 10 \text { visually impaired students } \\
\text { who are in the } 11-16 \text { age group and } 8 \\
\text { sessions was used. } \\
(\mathrm{N}=10)\end{array}$ & $\begin{array}{l}\text { Group conductors were able } \\
\text { to improve their empathy and } \\
\text { communication } \\
\text { skills in the group process in } \\
\text { spite of group constructors } \\
\text { meeted } \\
\text { member's blind corresponding. }\end{array}$ & $\begin{array}{l}\text { The group administrators, } \\
\text { in spite of the fact that they } \\
\text { have faced the difficulties } \\
\text { of visually impaired mem- } \\
\text { bers in the process, experi- } \\
\text { enced many opportunities } \\
\text { to develop many field skills, } \\
\text { especially communication } \\
\text { and empathy skills. }\end{array}$ \\
\hline$[10]$ & $\begin{array}{l}\text { To examine the changes } \\
\text { made by communica- } \\
\text { tion-focused intervention } \\
\text { in autistic children without } \\
\text { verbal communication and } \\
\text { to identify their benefits. }\end{array}$ & $\begin{array}{c}\text { Randomized controlled study } \\
73 \text { children, between the ages of } 4 \text { and } \\
10 \text {, from } 15 \text { different schools were } \\
\text { included and were practiced for } 9 \\
\text { months by being divided into groups. } \\
\text { (N:83) }\end{array}$ & $\begin{array}{l}\text { At the end of the 9th month, } \\
\text { the verbal communication } \\
\text { level of the experimental group } \\
\text { increased significantly. }\end{array}$ & $\begin{array}{l}\text { There is a small but } \\
\text { significant difference in } \\
\text { the initiation of children's } \\
\text { spontaneous communi- } \\
\text { cation. }\end{array}$ \\
\hline
\end{tabular}




\begin{tabular}{|c|c|c|c|c|}
\hline [11] & $\begin{array}{l}\text { To provide behavioral } \\
\text { changes in children with } \\
\text { persistent and challenging } \\
\text { behavioral disturbances }\end{array}$ & $\begin{array}{l}2 \text { therapists and } 6 \text { children were } \\
\text { included in the program. The program } \\
\text { was practiced in } 2 \text { steps. (N:6) }\end{array}$ & $\begin{array}{l}\text { The results of the behavior } \\
\text { change session were found } \\
\text { significant. }\end{array}$ & $\begin{array}{l}\text { Reductions and changes } \\
\text { in their standard harsh } \\
\text { behaviors were observed. }\end{array}$ \\
\hline [12] & $\begin{array}{l}\text { To prevent depression and } \\
\text { anxiety in elderly people } \\
\text { who are visually impaired } \\
\text { with the Progressive care } \\
\text { program }\end{array}$ & $\begin{array}{l}\text { Randomized controlled study } \\
\text { It contains a program consisting of } \\
\text { 4-stages. } \\
(\mathrm{N}: 230)\end{array}$ & $\begin{array}{l}\text { The practiced care program } \\
\text { was effective and the depres- } \\
\text { sion and anxiety scores of the } \\
\text { individuals were lower than } \\
\text { the control group. }\end{array}$ & $\begin{array}{l}\text { With the administered care } \\
\text { program, depression and } \\
\text { anxiety rates were reduced } \\
\text { in elderly individuals with } \\
\text { decreased visual acuity. }\end{array}$ \\
\hline [13] & $\begin{array}{l}\text { To evaluate the effec- } \\
\text { tiveness of the cognitive } \\
\text { rehabilitation program in } \\
\text { coping with cognitive dis- } \\
\text { abilities of MS patients }\end{array}$ & $\begin{array}{l}\text { An experimental study } \\
\text { The program was practiced once a } \\
\text { week throughout } 8 \text { weeks. } \\
(\mathrm{N}: 32)\end{array}$ & $\begin{array}{l}\text { The experimental group was } \\
\text { found to have a better level of } \\
\text { attention, memory, processing } \\
\text { speed and verbal fluency than } \\
\text { the control group. }\end{array}$ & $\begin{array}{l}\text { The practiced cognitive } \\
\text { rehabilitation program was } \\
\text { found effective in memory, } \\
\text { attention and speech areas } \\
\text { of MS patients. }\end{array}$ \\
\hline [14] & $\begin{array}{l}\text { To measure the effective- } \\
\text { ness of the Healing Path- } \\
\text { ways program in physically } \\
\text { disabled women who are } \\
\text { diagnosed with depression }\end{array}$ & $\begin{array}{l}\text { To measure the effectiveness of the } \\
\text { Healing Pathways program in physical- } \\
\text { ly disabled women who are diagnosed } \\
\text { with depression }\end{array}$ & $\begin{array}{l}\text { At the end of the } 14^{\text {th }} \text { week, } \\
\text { the depression level of the } \\
\text { experimental group decreased } \\
\text { significantly. }\end{array}$ & $\begin{array}{l}\text { Healing Pathways program } \\
\text { has been found to be effec- } \\
\text { tive in depressed women } \\
\text { with physical disabilities. }\end{array}$ \\
\hline [15] & $\begin{array}{l}\text { To evaluate the efficacy } \\
\text { of group therapies on MS } \\
\text { patients }\end{array}$ & $\begin{array}{l}\text { Randomized controlled study } \\
\text { The program was practiced once a } \\
\text { week throughout } 7 \text { weeks. } \\
\text { (N:29) }\end{array}$ & $\begin{array}{l}\text { When compared with the } \\
\text { experimental group, decrease } \\
\text { in depressive symptoms was } \\
\text { found to develop in } \\
\text { the short term. }\end{array}$ & $\begin{array}{l}\text { The study should be } \\
\text { repeated in different areas } \\
\text { and long term results } \\
\text { should be observed. }\end{array}$ \\
\hline [16] & $\begin{array}{l}\text { To measure the efficacy of } \\
\text { the self-esteem improve- } \\
\text { ment program for women } \\
\text { with disabilities }\end{array}$ & $\begin{array}{l}\text { Randomized controlled study } \\
\text { The program consisting of } 5 \text {-step was } \\
\text { practiced for } 6 \text { weeks. } \\
\text { (N:102) }\end{array}$ & $\begin{array}{l}\text { At the end of the 6th week, the } \\
\text { self-esteem level scores of the } \\
\text { test group increased signifi- } \\
\text { cantly. }\end{array}$ & $\begin{array}{l}\text { Self-esteem improve- } \\
\text { ment program was found } \\
\text { effective in women with } \\
\text { disabilities. }\end{array}$ \\
\hline [17] & $\begin{array}{c}\text { To measure the efficacy } \\
\text { of psychotherapy services } \\
\text { by communicating via PC } \\
\text { and to reduce the feeling } \\
\text { of loneliness with relay } \\
\text { chat and targeted BD group } \\
\text { teletherapy }\end{array}$ & $\begin{array}{l}\text { A pretest-posttest experimental study } \\
\text { A total of } 19 \text { people consisting of } 7 \\
\text { groups of } 2-3 \text { people were included. } \\
\text { Participants were monitored } 1 \text { day per } \\
\text { week for } 4 \text { months. } \\
\text { (N:19) }\end{array}$ & $\begin{array}{l}\text { Participants indicated that } \\
\text { they were less lonely in the } \\
\text { final test. }\end{array}$ & $\begin{array}{l}\text { At the end of the study } \\
\text { indicate that participants } \\
\text { felt less lonely after } \\
\text { intervention than a similar } \\
\text { group that had been placed } \\
\text { in a waiting-list control. } \\
\text { Also results indicate that } \\
\text { gains were maintained at a } \\
\text { 4-month follow-up. }\end{array}$ \\
\hline [18] & $\begin{array}{l}\text { To evaluate the effica- } \\
\text { cy of a novel telehealth } \\
\text { intervention, “CareCall", on } \\
\text { reducing pressure ulcers } \\
\text { and depression. }\end{array}$ & $\begin{array}{l}\text { "Care Call" is an automated, interac- } \\
\text { tive voice response system that have } \\
\text { patient education, } \mathrm{CB} \\
\text { interventions, screening and referrals } \\
\text { (N:142) }\end{array}$ & $\begin{array}{l}\text { "Care Call" achieved a reduc- } \\
\text { tion in presence of pressure ul- } \\
\text { cers at } 6 \text { months in women and } \\
\text { "CareCall" reduced 6-month } \\
\text { severity of depression, adjust- } \\
\text { ing for age and gender. }\end{array}$ & $\begin{array}{l}\text { The aim is achieved as a } \\
\text { result of studying }\end{array}$ \\
\hline [19] & $\begin{array}{l}\text { Aim of this study to exam- } \\
\text { ine effects of parent-child } \\
\text { dyads' participation in a } \\
\text { six-week home-based mu- } \\
\text { sic therapy program. }\end{array}$ & $\begin{array}{c}\text { Parent-child dyads participated in a } \\
\text { home-based music therapy program } \\
\text { that included six weekly } 40 \text {-minute } \\
\text { sessions, } \\
\text { and incorporated five responsive } \\
\text { teaching strategies } \\
\text { (N:26) }\end{array}$ & $\begin{array}{l}\text { Parents' positive physical and } \\
\text { verbal responses, as well as } \\
\text { children's positive verbal initi- } \\
\text { ations, increased significantly } \\
\text { pre- to postintervntion }\end{array}$ & $\begin{array}{l}\text { Findings support the use of } \\
\text { home-based music therapy } \\
\text { programs to facilitate } \\
\text { parent-child interactions in } \\
\text { the areas of parental } \\
\text { responsiveness and } \\
\text { child-initiated communica- } \\
\text { tion, as well as parent child } \\
\text { synchrony }\end{array}$ \\
\hline
\end{tabular}

When the psychiatric rehabilitation programs for disabled people were examined in the mentioned databases, a total of 7413 studies were reached. When studies were analyzed via the PRISMA (Preferred Reporting Items for Systematic Reviews and Meta-Analyses) scheme by considering the inclusion criteria, 14 studies (Table 1) were considered appropriate and included. When studies are examined, it is seen that there are various cognitive, behavioral and socially supporting programs towards disabled people. Out of 14 studies examined, 7 of them are programs towards children and teenagers with autism, cerebral palsy and sight-disability, 1 of them towards elderly people with sight-disability, 6 of them towards adults with multiple sclerosis, physical or sight disability. In studies examined, it is seen that "Virtual Reality Therapy" (Table 2) practiced on children with cerebral palsy increases spiritual adaptation, "Picture Exchange Communication System (PECS)" practiced on children with 
autism provides a progress in social communication skills, "Communication-based Intervention Program" practiced on children with both autism and lack of verbal communication makes a significant difference in starting the conversation and "Interpersonal Communication Skills Psycho-Education Program" and "Structured Experience of Group Process" practiced on teenagers with sight disability are effective on increasing the empathetic tendencies and communication skills of teenagers.

In consequence of psychoeducation program practiced on elderly individuals with visual impairment, it is seen that depression and symptoms of anxiety reduce, "Healing Pathways" program practiced on physically disabled women with depression diagnosis decreases the points of depression and reduces its symptoms, "Development Programs of Self Esteem" increases the points of self esteem level significantly. Besides, with the development of technology, as a result of practicing telepsychiatry and telehealthprograms which have been often used recently on physically disabled people, it is seen that breakoff phenomenon and depressive symptoms are reduced in people.

\section{Conclusion}

With this mini-literature review, the psychiatric rehabilitation programs were revised and it was seen that the programs improved problem solving skills in disabled people, increased perceptions of family communication, social support, self esteem and decreased mood problems such as anxiety and depression. Besides programs examined, teaching daily life skills, assisted living and employment programs, sensory integration therapies, social skills education, behavioral change (regulation) education and spiritual education of the family towards disabled individuals exist and they are practiced.

\section{Reference}

1. http://www.resmigazete.gov.tr/eskiler/2005/07/20050707-2.htm.

2. http://www.resmigazete.gov.tr/eskiler/2010/12/20101216M1-1. htm

3. World Health Organization-WHO (2011) International Classification of Functioning and Disability- ICIDH.

4. Liberman RP (2009) Illness Management. Recovery From Disability Manual of Psychiatric Rehabilitation. American Psychiatric Publishing, England, p: 89-152.

5. Ylldız M (2015) Psychiatric Rehabilitation: Psychiatric Health from Person to Society (Psikiyatrik Rehabilitasyon. Bireyden Topluma RuhSağlığı). IşıkSayıl (Ed.), Erler Puplication, Istanbul, pp: 151-164.
6. MetinÖkmen B, Doğan Aslan M, ÇuhadaroğluÇetin F, NakipoğluYüzer GF, KöseDönmez B, et al. (2013) The Effect of Virtual Reality Therapy on Psychological Adaptation in Children with Cerebral Palsy. Archives of Neuropsychiatry 50(1): 70-74.

7. Lerna A, Esposito D, Conson M, Russo L, Massagli A (2012) SocialCommunicative Effects of The Picture Exchange Communication System (PECS) In Autism Spectrum Disorders. Int J Lang Commun Disord 47(5): 609-617.

8. Ylldız MA, Duy B (2013) Improving Empathy and Communication Skills of Visually Impaired Early Adolescents through a PsychoEducation Program. Educational Sciences: Theory and Practice 13(3): 1470-1476.

9. Karaca S, Özaltin G (2010) Experience with Structural Group Process: What Does a Group Process Executed with Blind Adolescents Teach? J Psy Nurs 1(2): 77-85.

10. Gordon K, Pasco G, McElduff F, Wade A, Howlin P, et al. (2011) A Communication-Based Intervention For Nonverbal Children With Autism: What changes? Who benefits? J Consult Clin Psychol 79(4): 447-457.

11. Sterkenburg PS, Janssen CGC, Schuengel C (2008) The Effect of an Attachment-Based Behaviour Therapy for Children with Visual and Severe Intellectual Disabilities. Journal of Applied Research in Intellectual Disabilities 19(3): 1-237.

12. Van der Aa HP, Van Rens GH, Comijs HC, Bosmans JE, Margrain TH, et al. (2013) Stepped-care to prevent depression and anxiety in visually impaired older adults--design of a randomised controlled trial. BMC psychiatry 13: 209.

13. AltunI G, Kırbaş D, Altun DU, Soysal A, Sütlaş PN, et al. (2015) The Effects of Cognitive Rehabilitation on Relapsing Remitting Multiple Sclerosis Patients. Noro Psikiyatr Ars 52(2): 174-179.

14. Hassouneh D, Nguyen T, Chen Z, McNeff E (2013) Healing Pathways: A Program For Women With Physical Disabilities And Depression. Hindawi Publishing Corporation Rehabilitation Research and Practice.

15. Tesar N, Baumhackl U, Kopp M, Günther V (2003) Effects of Psychological Group Therapy in Patients With Multiple Sclerosis. Acta Neurol Scand 107(6): 394-399.

16. Hughes RB, Robinson-Whelen S, Taylor HB, Swedlund N, Nosek MA, et al. (2004) Enhancing Self-Esteem in Women with Physical Disabilities. Rehabilitation Psychology 49(4): 295-302.

17. Hopps SL, Pépin M, Boisvert JM (2003) The Effectiveness Of CognitiveBehavioral Group Therapy For Loneliness Via Inter Relaychat Among People With Physical Disabilities. Psychotherapy Theory Research \& Practice, Training 40(1-2): 136-147.

18. Houlihan BV, Jette A, Friedman RH, Paasche-Orlow M, Ni P, et al. (2013) A pilot study of a telehealth intervention for persons with spinal cord dysfunction. Spinal Cord 51(9): 715-720.

19. Yang YH (2016) Parents and Young Children with Disabilities: The Effects of a Home-Based Music Therapy Program on Parent-Child Interactions. J Music Ther 53(1): 27-54. 
This work is licensed under Creative Commons Attribution 4.0 License DOI: 10.19080/JYP.2017.01.555570

\section{Your next submission with Juniper Publishers will reach you the below assets}

- Quality Editorial service

- Swift Peer Review

- Reprints availability

- E-prints Service

- Manuscript Podcast for convenient understanding

- Global attainment for your research

- Manuscript accessibility in different formats ( Pdf, E-pub, Full Text, Audio)

- Unceasing customer service

Track the below URL for one-step submission https://juniperpublishers.com/online-submission.php 